\title{
The Impact of Tort Reform on Employer-Sponsored Health Insurance Premiums
}

\author{
Ronen Avraham \\ University of Texas at Austin, School of Law \\ Leemore S. Dafny \\ Kellogg School of Management, Northwestern University and NBER \\ Max M. Schanzenbach \\ Northwestern University, School of Law
}

September 2009

\begin{abstract}
We evaluate the effect of tort reform on employer-sponsored health insurance premiums by exploiting state-level variation in the timing of reforms. Using a dataset of healthplans representing over 10 million Americans annually between 1998 and 2006, we find that caps on non-economic damages, collateral source reform, and joint and several liability reform reduce premiums by 1 to 2 percent each. These reductions are concentrated in PPOs rather than HMOs, suggesting that can HMOs can reduce "defensive" healthcare costs even absent tort reform. The results are the first direct evidence that tort reform reduces healthcare costs in aggregate; prior research has focused on particular medical conditions.
\end{abstract}

e-mail: ravraham@law.utexas.edu, 1-dafny@kellogg.northwestern.edu, m-schanzenbach@law.northwestern.edu.

We are grateful for helpful comments by Jennifer Arlen, David Dranove, Jonathan Klick, Robert Kaestner, and participants at the American Association of Law and Economics Annual Meetings, the University of Illinois at Chicago, and the Searle Center Symposium on Civil Liability. This research was funded by The Searle Center on Law, Regulation, and Economic Growth at the Northwestern University School of Law. 
For many years, policy makers have been searching for measures that will reduce the growth in healthcare costs. One approach that has gained increasing attention is tort reform, a broad term encompassing various laws that limit the tort exposure of healthcare providers. Physician groups, private health insurers, and both Presidents Bush and Obama have argued that tort reform will reduce healthcare costs. ${ }^{1}$ As a theoretical matter, however, limiting tort liability could increase or decrease healthcare costs. On the one hand, liability incentivizes health providers to take greater precautions and avoid unnecessary or risky procedures. Thus, reducing the liability of providers could increase costly medical errors and the practice of "inducing" demand, i.e. delivering profitable but unnecessary and potentially risky treatments. On the other hand, critics of the tort system argue that courts lack the capability to accurately identify negligent care, and further that providers' sensitivity to liability leads to excessive care (or "defensive medicine"). The net impact of reform is an empirical question of significant policy interest.

In this study, we exploit variation in state-level timing of reforms to assess the impact of specific types of reform on employer-sponsored health insurance premiums. Most non-elderly Americans receive health benefits through such plans, so premiums are a strong indicator of the impact of reforms on aggregate costs. We identify four specific reforms with sufficient enactment/strikedown activity to be evaluated during our study period: caps on non-economic damages, caps on punitive damages, collateral source reform, and joint and several liability reform. We match state-level data on the timing of these reforms to a privately-gathered national database of insurance contracts agreed upon by a sample of large, multisite employers between 1998 and 2006 . We separate the sample into fully-insured and self-insured contracts, as both product characteristics and

\footnotetext{
${ }^{1}$ President's Remarks at the 2004 President's Dinner. Available at http://www.whitehouse.gov/news /releases/ 2004/07/20040721-14.html. Presidential Debate Transcript (10/15/2008). Available at http://today.msnbc.msn.com/id/27086587/page/4/. America's Health Insurance Plans (AHIP) buys advertisements promoting tort reform, arguing that medical malpractice liability has increased the cost of providing health insurance. AHIP asserts that "the current litigation system for compensating patients injured by medical negligence is expensive, slow, and does little to benefit the injured patients". Available at http://www.ahip.org/content/default.aspx?bc=39|341|320.
} 
regulations differ by this distinction. ${ }^{2}$ We also examine whether the impact of reform varies by plan type, specifically managed vs. non-managed plans. Kessler and McClellan (2002) find that tort reform and managed care are to some extent substitutes for each other. Just as tort reform reduces the incentive for doctors to undertake defensive medicine, HMOs manage care to reduce unnecessary procedures.

We find evidence that each of these reforms, save caps on punitive damages, is associated with reductions of 1-2 percent in self-insured premiums. By contrast, there is little evidence that tort reform affects fully insured premiums. The limited response of fully insured premiums is consistent with the dominance of HMOs in this market. We confirm this by separating responses among the insurance types within the self-insured sample. As expected, most of the observed reductions are attributable to premium decreases for PPOs rather than managed-care plans (HMOs and point-of-service (POS) plans).

We extend our analysis by investigating whether the estimated effects are moderated in local markets with less competition among insurers. To the extent insurers possess market power, the pass-through of cost reductions due to tort reform will be incomplete. Using the same insurance data source, Dafny (2009) finds evidence that insurers exercise market power in an increasing number of local geographic markets. Consistent with our hypothesis, we find suggestive evidence that pass-through of savings is largest in the most competitive markets.

The paper proceeds as follows. Section I provides background on tort reform and reviews relevant prior work. Section II discusses the data, Section III the identification strategy, and Section IV the results. Section V concludes.

\footnotetext{
${ }^{2}$ In a "self-insured" plan, employers are responsible for their employees' medical costs, though employers retain a health plan as an administrator and may purchase stop-loss coverage. By contrast, in a "fully insured" plan the insurer is responsible for payment.
} 


\section{Tort Reform and Healthcare Costs}

Tort reform can affect healthcare costs through two mechanisms: (1) direct liability costs and (2) costs associated with intensity of treatment. Liability costs are comprised of medical malpractice premiums, malpractice damage awards in excess of premiums, and the associated litigation costs. ${ }^{3}$ These costs are generally believed to comprise a small share of total healthcare costs, at most two percent (Congressional Budget Office 2004). Therefore, tort reform cannot plausibly reduce healthcare costs much by limiting liability costs. If tort reform is to have a substantial effect on healthcare costs, it must affect treatment intensity, which implies that providers must be sensitive to liability pressures.

As noted, the effect of tort reform on treatment intensity is theoretically ambiguous. Indeed, the potential for tort law to improve or distort incentives to provide optimal care has long been debated in both the legal and economic literature. Ideally, tort law encourages providers to take proper precautions and yields improvements in patient care. While extra care may mean more spending on treatments, it may reduce costs arising from medical errors. There is certainly strong evidence of high rates of preventable medical errors. ${ }^{4}$ In recognition of the depth of this problem, the Centers for Medicare and Medicaid Services recently implemented tougher reimbursement policies for treatment provided to correct medical errors. ${ }^{5}$ In addition, tort liability may deter doctors from pursuing unnecessarily risky but profitable courses of treatment. There is also ample evidence that physicians "induce demand" when there are financial rewards to doing so (see Gruber et al (1999) for a review).

However, tort law may distort incentives as well. Tort liability may be only weakly correlated with negligent care, yielding few benefits. (The failure of malpractice insurance companies to systematically experience-rate physicians constitutes suggestive

\footnotetext{
${ }^{3}$ The administrative costs of the courts are largely socialized. Of course, plaintiffs bear a portion of the litigation costs as well; we do not explicitly consider these in our discussion.

${ }^{4}$ The Institute on Medicine (2000), relying on several epidemiological studies that reviewed actual patient records, concluded that between 44,000 and 98,000 people die each year due to "preventable medical errors." The report is available at http://www.iom.edu/Object.File/Master/4/117/ToErr-8pager.pdf.

5 "Not Paying for Medical Errors," The New York Times, August 21 ${ }^{\text {st }}, 2007$.
} 
evidence for this view.) Worse still, the threat of liability could persuade physicians to prescribe tests and procedures that are not medically necessary, but which may help the physician avoid litigation. Defensive medicine thereby piles on costs borne not by the physician but by the patient and insurers, and by definition provides little (and potentially negative) value to patients.

\section{a. Tort reform and malpractice liability}

Recent work confirms that tort reform is effective in reducing physicians' liability exposure. ${ }^{6}$ In his survey of the literature, Holtz-Eakin (2004) concludes caps on damages are consistently found to reduce the number of lawsuits and the size of awards. Most recently, Avraham (2007) examines medical malpractice settlements. He finds that some tort reforms decrease the number of claims by roughly five to thirteen percent and total annual payouts by more than fifteen percent. ${ }^{7}$ The reduction in the probability of lawsuits may have a greater impact on provider behavior than the reduction in awards themselves. Medical malpractice insurance and the bankruptcy remoteness of many assets (such as homes and retirement savings) generally protect physicians from having to pay large awards. As a result, the reduction in the probability of a lawsuit (with its attendant damage to reputation and psychic and time costs of litigation) may be more relevant to providers' behavior than the actual financial risk they face.

Another strand of this literature assesses the effect of tort reform on medical malpractice insurance premiums. This literature finds limited evidence that rates of

\footnotetext{
${ }^{6}$ Early studies on tort reform focused mainly on the impact of tort reform on direct medical liability costs such as average award size, frequency of lawsuits, or the price of malpractice insurance. Other studies have explored the effect of tort reform on medical malpractice insurance variables such as premiums, loss ratio, and losses incurred. These studies often found mixed results and were plagued with selection issues (for reviews of previous literature see Zuckerman, Koller, and Bovbjerg [1986]; Holtz-Eakin [2004]).

${ }^{7}$ Specifically, Avraham (2007) finds that caps on non-economic damages and limitation of the doctrine of joint and several liability reduced the number of annual payments, and that caps on non-economic damages and periodic payment reform reduced average awards. Additionally, caps on non-economic damages were found to reduce total awards, although this finding was only weakly significant.. The other reforms had no statistically significant effect on total annual payments. In their working paper, Currie and MacLeod (2006) also find that reforms reduced malpractice payouts.
} 
growth in malpractice premiums have been slower on average in states that enacted caps on pain and suffering damages than in states with more limited reforms. ${ }^{8}$

\section{b. Tort reform, physician behavior, and healthcare costs}

As noted earlier, the direct effects of tort reform (on litigation costs, damage awards, and malpractice premiums) are unlikely to generate sizeable decreases in healthcare costs. For this reason, many researchers focus attention on the reaction of providers to tort reform.

To date, all of the empirical work on provider responses to tort reform focuses on a specific condition, namely heart disease or pregnancy. The most frequently cited evidence that tort reforms reduce healthcare costs is from Kessler and McClellan (1996). Using data on all elderly Medicare beneficiaries treated for serious heart disease in the years 1984, 1987, and 1990 and a panel of state reforms, Kessler and McClellan find that "direct" reforms (such as limitations on damages) reduce medical costs by 5 to 9 percent within 3 to 5 years of adoption without substantially affecting mortality or medical complications. ${ }^{9}$ Kessler and McClellan (2002) obtain similar estimates using more recent data for the same population, and they also document smaller impacts in states with greater HMO penetration. They conclude that tort reform and managed care are partial substitutes. Tort reform reduces the incentives of doctors to supply defensive medicine, while managed care may actively prevent doctors from undertaking defensive medicine. Thus we anticipate that tort reform will have a smaller impact on premiums for managed care plans, a hypothesis we can test directly because our data identifies plan types.

The evidence from a different medical condition, pregnancy, is mixed. Dubay, Kaestner, and Weidman (1999) find greater liability pressures are associated with increased use of Caesarean sections, and no improvement in infant Apgar scores. Sloan et al (1995) also find no systematic improvement in birth outcomes (birthweight and Apgar scores) due to greater liability pressure. Consistent with the conclusions of

\footnotetext{
${ }^{8}$ Danzon et al (2004) and GAO (2003).

${ }^{9}$ Kessler and McClellan (1996, pp. 371-2). The "direct" reforms include: caps on pain-and-suffering damages, caps on punitive damages, abolition of the collateral source rule and mandatory prejudgment interest. The "indirect" reforms include: contingency fee reforms, periodic payments, joint and several liability, and patient compensation funds.
} 
Kessler and McClellan, these findings suggest tort reforms reduce costs with no adverse effect on outcomes. Recent work by Currie and MacLeod (2008), however, suggests the reverse for some reforms. Currie and MacLeod find that caps on damages and collateral source reform increase the complication rate for deliveries and the use of more expensive procedures. The authors conclude that limitation of liability makes it easier for physicians to pursue riskier procedures that are more remunerative but offer no offsetting benefits to patients. If this result generalizes across specialties and procedures, certain reforms could increase health care costs as physicians induce demand, less encumbered by the threat of liability. By contrast, Currie and MacLeod find that joint and several liability reform improves outcomes because it places more liability on the doctor (as opposed to the hospital and other providers), who may have the most control over care.

In sum, the research focusing on individual conditions is inconclusive. Moreover, it is difficult to estimate the net effect of tort reforms on healthcare costs by extrapolating from studies on specific conditions. The insurance data we use enables us to provide an estimate of the aggregate effect of reform. A key disadvantage, however, is that we will be unable to assess how these reforms impact health outcomes, which are very difficult to aggregate across a broad swath of conditions.

\section{c. Tort reform and Insurance Plans}

As previously noted, tort law may have different impacts across insurance plans. If managed care plans effectively monitor utilization through review, gatekeepers, or financial incentives, then tort reform and managed care may be substitutes. Research prior to the mid-1990s found that HMOs reduced treatment intensity by as much as fifteen percent. (See Glied 2000 for a literature survey). Papers using data from the last ten years are more mixed, suggesting that HMOs and other plan types have converged as even indemnity plans have adopted some utilization review. (See Glied 2003 for a literature survey). Most starkly, Altman et al. (2003), using a database of Massachusetts state employees, found that while HMOs were substantially less costly, little if any of the difference could be attributed to reductions in treatment intensity. By contrast, Carlin and Town (2008), using claims data from 2002-2005 for a large, self-insured Midwestern 
employer, find HMOs use 16 percent fewer "relative value units"10 than other plans (which are POS or CDHP plans), conditional on the same health status of the insured population. In sum, the literature suggests that managed care has potential to reduce treatment intensity, but the magnitude is disputed.

Because we can measure the effect of tort reform on HMO premiums versus other types of coverage, such as PPOs, we can directly estimate the effect of tort reform on premiums for different insurance types. We can also distinguish between the funding arrangement for each plan type (i.e. self insured versus fully-insured). The responsiveness of self-insured HMO premiums to tort reform may be further attenuated because federal law exempts self-insured plans from state tort liability for wrongful denial of coverage (though provider liability for negligence remains).

\section{Data}

Our primary source is the Large Employer Health Insurance Dataset (LEHID). LEHID contains information on all of the healthplans offered by a large and non-random sample of employers between 1998 and 2006, inclusive. LEHID is gathered and maintained by a leading benefits consulting firm, and the employers included in the dataset have some past or present affiliation with the firm. The unit of observation is the healthplan-year. A healthplan is defined as a unique combination of employer, market, insurance carrier, and plan type, e.g. Company X's Chicago-area Aetna HMO. We now discuss each of the components that jointly identify this unit of observation in turn.

The full dataset includes observations from 813 employers. Most employers are large, multi-site, publicly-traded firms, such as those included on the Fortune 1000 list. The leading industries represented include manufacturing (110 employers), finance (101), and consumer products (73), although nonprofit and government sectors are also represented (43 in the "government/education" category). Employers may enter or exit the sample at any time. The median number of years an employer is present in the sample is two. One-quarter of employers appear in the sample for 4 or more years. A

\footnotetext{
${ }^{10}$ Medicare developed the Resource-Based Relative Value Units scale to measure the resources used to provide care, so this implies the gatekeeper function results in fewer resources consumed by enrollees. This result does not incorporate differences in the prices paid to providers, which may compound the cost advantage of HMOs.
} 
small number of employers reappear after exiting. Given the frequency of exit and entry into the sample, it is not feasible to restrict analysis to a balanced sample of firms. We revisit this issue in the empirical analysis below.

Geographic markets are defined by the source using 3-digit zip codes. The 139 markets reflect the geographic boundaries used by insurance carriers when quoting premiums, and collectively cover all of the continental U.S., with the exception of a few rural areas. Large metropolitan areas are separate markets, and non-metropolitan areas are lumped together within state boundaries, e.g. "New Mexico - Albuquerque" and "New Mexico - except Albuquerque." "11

Each firm that administers any plan in the data is labeled an "insurance carrier." During the entire study period, there are 357 carriers that serve at least one employer, of which 195 serve 5 or more. The smaller carriers tend to be local or regional firms, or sometimes "third party administrators" who pay claims and contract with another carrier to "rent" its network of providers and associated discounts.

The plan types, ordered from most to least restrictive in terms of provider choice, are Health Maintenance Organization (HMO), Point of Service (POS), Preferred Provider Organization (PPO), and Indemnity. HMOs and POS plans control utilization of care through primary-care physicians ("gatekeepers"). Only in-network providers are covered by HMOs, while POS plans provide some coverage for out-of-network providers (once the gatekeeper has approved the service in question). PPOs engage in less utilization management, and like POS plans, typically cover out-of-network care at a reduced rate. Finally, indemnity plans are traditional fee-for-service arrangements in which benefits do not depend on the network status of the provider.

In addition to the elements that jointly define a plan, we have the following variables: premium, insurance type, demographic factor, plan design factor, and number of enrollees. Premium is expressed as an average amount per enrollee; it therefore increases with the average family size of enrollees in a given plan. Premium combines employer and employee contributions. The definition of premium depends on insurance type, which refers to whether a plan is self-insured or fully insured. Many large

\footnotetext{
${ }^{11}$ There is only one market that crosses state boundaries, "Massachusetts - Southern and Rhode Island." A map of the markets is available in Dafny (2008).
} 
employers choose to self-insure, outsourcing benefits management and claims administration but paying realized costs of care. Such employers can spread risk across large pools of enrollees, and often purchase stop-loss insurance to limit their exposure.

Demographic factor is a measure that reflects the family size, age, and gender composition of enrollees in a given plan. Plan design factor captures the generosity of benefits for a particular plan-year, including copays. Both factors are calculated by the source, and the formulae were not disclosed to us. The number of enrollees in LEHID plans averages 4.7 million per year. Given an average family size above 2, this implies roughly 10 million Americans are represented in the sample in a typical year.

Appendix Tables 1 and 2 present descriptive statistics for self-insured and fully insured plans, respectively. Notable in Table 2 is the steep decline in the number of fully insured plans from 2004-2006. This decline mirrors declines observed in data on similarsized firms from the Medical Expenditure Panel Survey-Insurance Component, which conducts semi-regular annual surveys of employers of sampled individuals. ${ }^{12}$ There are several possible reasons fully insured plans have become less attractive for large firms, including the diminishing distinction between non-HMOs and HMOs (sometimes available only as a fully insured product), and the potential that insurance carriers are charging increasing risk premia (perhaps due to market power). This is an important subject for future research. For the present study, our main concern is that selection out of full insurance could be correlated with the timing of reform; we address this in the empirical work that follows and find no such pattern.

We also note that some multisite firms may negotiate deals entailing the same premium for a given plan across multiple locations. Unfortunately, we cannot identify observations belonging to such agreements, nor is it possible to use observed premiums to infer which plans are part of such a contract. ${ }^{13}$ However, to the extent such agreements take place, our estimates will be conservative: premiums for such plans cannot exhibit state-specific responses to any reforms.

\footnotetext{
${ }^{12}$ We are grateful to Kosali Simon for tabulating the MEPS-IC data to investigate this trend.

${ }^{13}$ We observe the average premium per plan-year, where a plan is a unique combination of employer, market, insurance carrier, and plan type. Even if Company X's Blue Cross HMO has the same premium, by family size, across all markets, the average premium will take on different values across these markets due to differences in family size at each site.
} 
Before proceeding to the analyses, we evaluate the representativeness of the LEHID data. The best source for nationally-representative estimates of employersponsored health insurance premiums is the annual Employer Health Benefits Survey, sponsored jointly by the Kaiser Family Foundation (KFF) and the Health Research and Educational Trust (HRET). ${ }^{14}$ Using these data, KFF/HRET report the average growth in premiums for a family of four. Although we would not expect premium levels to be similar for this sample and the LEHID sample (both because the selection of firms is nonrandom and because family sizes differ across plans), if growth rates are similar this would suggest the results of our study are applicable to a broader sample of employers because all specifications rely on premium growth over time. Appendix Figure 1 graphs the annual growth rate for employee-weighted premiums against that reported by KFF/HRET. The trends in both samples are very similar over time. Dafny (2009) also reports that the ratio of sampled enrollees to total insured lives (available at the countylevel from the US Census of 2000) varies little across geographic markets.

\section{Identification Strategy}

We identify the effect of tort reform based on changes to state laws. Throughout our analysis we carefully consider the risk of legislative endogeneity, i.e. the possibility that changes in premiums prompt the passage of laws rather than vice versa. This may be of particular concern because at times tort reforms were limited to medical malpractice instead of applying generally (e.g., to product liability and automobile accidents). We will rely on trends in the data immediately prior to the passage of reforms to assess the likelihood of this threat to the identification strategy.

We conduct our analysis separately for self-insured and full-insured plans. In a "self-insured" plan, employers are responsible for their employees' medical costs, though employers retain an insurance carrier as an administrator and may purchase stop-loss coverage. By contrast, in a "fully insured" plan the insurer is responsible for payment.

\footnotetext{
${ }^{14}$ The KFF/HRET survey randomly selects public and private employers to obtain national data about employer-sponsored health insurance; approximately 2000 employers respond each year. The data are not publicly available, nor is the sample designed to provide estimates at the market level
} 
There are three reasons to consider these plan types separately. First, they are different products and hence have different pricing. Reported self-insured plan "premiums" are actually estimates of employers' projected healthcare expenditures, rather than final figures that reflect all expenses, including risk premiums charged by insurers. ${ }^{15}$ Second, self-insured plans are regulated under the Employee Retirement and Income Security Act (ERISA) at the national level and are exempt from state regulations, including health insurance premium taxes and mandated benefits. The regulatory uniformity of selfinsured plans reduces the chances for legislative endogeneity of state reforms in this sample. For example, a state that enacts an expensive mandate for infertility benefits may experience large fully-insured premium increases and enact tort reforms to offset them. The benefit mandate would not impact self-insured plans in that state. (Of course, we test for the presence of legislative endogeneity empirically, but a priori this concern is lesser in the self-insured sample.) Finally, in our sample over $90 \%$ of fully insured plans are offered by Health Maintenance Organizations (HMOs), which engage in greater utilization review and employ gatekeeper physicians. HMOs have greater incentive and ability to reduce unnecessary care even absent tort reform, hence responses in the fullyinsured sample may be attenuated.

\section{a. Timing of tort reform}

We date tort reforms using the third edition of the Database of State Tort Law Reforms (DSTLR $3^{\text {rd }}$ ). This dataset, discussed at length in Avraham (2006), was assembled by reviewing the laws and court cases of the 50 states (and Washington DC) from 1980 to 2008 and comparing them to existing tort law compilations. ${ }^{16}$ The process revealed that commonly used dating schemes suffer from missed reforms, missing or erroneously coded effective dates of reforms, and missing or erroneously coded state supreme court decisions striking down or upholding reforms. The DSTLR $3^{\text {rd }}$ edition is

\footnotetext{
${ }^{15}$ Stop loss premiums are included in these estimates, but the amount of coverage is not the same across all employers (and some do not purchase any).

${ }^{16}$ The dataset is available for free download at: http://papers.ssrn.com/sol3/papers.cfm?abstract_id=902711. The compilations include: The American Tort Reform Association's compilation (2007); a compilation by the National Conference of State Legislators (2007); American Medical Liability Association's Comparison of State Medical Liability Laws; Westlaw's 50 State Survey (2006); Congressional Research Service (2005).
} 
the most comprehensive and accurate dataset on tort reform legislation to date. Currie and MacLeod (2008) provide independent corroboration of the tort reform timings used here.

There are seven common tort reforms enacted during the period under study. They include a variety of damage caps, damage payment reforms, and reforms of joint and several liability. ${ }^{17}$ However, we have sufficient variation during our study period (1998 to 2006) to analyze only four in detail: caps on non-economic damages, caps on punitive damages, reform to the collateral source rule, and limits on joint and several liability. (For robustness, we also estimate models using the simple count of the seven common reforms.) Appendix Table 3 lists the states enacting and repealing all seven reforms during our study period. ${ }^{18}$ Note that reforms are coded as of July $1^{\text {st }}$, and refer to effective dates as opposed to enactment dates. We now describe the four key reforms in greater detail., emphasizing the number of changes to each that occur between 1998 and 2005. (Because premiums for 2006, our final year of premium data, are set in 2005, only changes in law through 2005 are effectively incorporated in our analysis.)

Caps on Non-Economic Damages. Non-economic damages encompass pain and suffering, loss of enjoyment of life, and loss of consortium. Such damages can comprise a significant fraction of total damage awards and have often been the focus of tort reform advocates. ${ }^{19}$ Caps vary across many dimensions. Some reforms impose a cap of a fixed dollar amount, while others use a multiplier of the economic damages. Some are indexed to inflation, some are not. In addition, the level of caps varies from state to state. By 2007, twenty-six states had capped non-economic damages. Between 1998 to 2005

\footnotetext{
${ }^{17}$ Reforms related to patient compensation funds are excluded from this list for lack of activity during the study period. A patient compensation fund is a state fund which usually pays medical malpractice victims monies if the damages awarded are above some threshold, such as $\$ 400,000$. The rationale is that the fund lowers physicians' premiums and spreads the risk of risky medical specialties across the entire population of physicians and taxpayers. In the mid-1980s, a few states changed their policies regarding contingency fees, capping plaintiffs' lawyers' share in the recovery.

${ }^{18}$ Because health insurance premiums are set prospectively, our baseline models lag the reform indicators by one year. For this reason, the table and ensuing discussion refer to changes that take effect during the years 1998-2005, inclusive.

${ }^{19}$ Avraham (2006) cites sources claiming that non-economic damages account for up to $50 \%$ of total recoveries in product liability cases.
} 
twelve states enacted or struck down caps on non-economic damages for medical malpractice.

Caps on Punitive Damages. Punitive damages are those in excess of actual losses suffered and are intended, as the name implies, to punish the perpetrator. By 2007 thirty states had enacted caps on punitive damages. Between 1998 to 2005 nine states enacted or struck down caps on punitive damages, one of which applies only to medical malpractice (Maine). Punitive damages are reputed to be rare in the case of medical malpractice. However, as Polinsky (1997) argues, even the remote possibility of large damage claims may have a significant impact on providers' behavior.

Collateral Source Reforms. Discretionary or mandatory consideration of collateral sources of payment for medical costs is one of the most common tort reforms. The collateral source rule was developed by common law courts in the $19^{\text {th }}$ century when insurance became more common. The rule generally holds that the plaintiff's personal insurance coverage cannot be used to offset the defendant's share of damages. The result is that an insured plaintiff may receive more than his full harm in the case of an accident. States coded as having reformed the collateral source rule have abrogated the common law and either require or allow courts to reduce the plaintiff's recovery by the amount of private or public insurance benefits he receives (taking into account the accumulated paid premium). By 2007 thirty-four states had reformed the collateral source rule in this way. Between 1998 to 2005, six states enacted or struck down the collateral source rule for medical malpractice claims. In addition, Alabama reformed the collateral source rule for all types of claims.

Joint and Several Liability. Under the common law rule of joint and several liability, the plaintiff can collect the entire damages award from any of the defendants found liable in the lawsuit, regardless of their percentage of liability. This allows plaintiffs to pursue defendants with "deep pockets" and collect the full recovery from them. In medical malpractice cases, the deep pockets are likely hospitals and practice groups. States have limited plantiffs' access to deep pockets by modifying the joint and several liability rule in various ways, primarily by limiting each defendant's liability to its proportional share. This forces patients to collect more from individual doctors, who typically bear the largest share of responsibility for negligence. Thus, joint and several 
liability reform puts greater liability pressure on doctors and reduces that on other providers. In addition, joint and several liability reform may limit the amount of recovery a plaintiff can make, not unlike a cap. Doctors are not deep pockets because they have insurance coverage limits and personal assets that are protected in the case of bankruptcy, effectively capping plaintiffs' recoveries. Between 1998 to 2005 six states enacted or struck down reforms of the joint and several liability rule, one of which applied solely to medical malpractice (Nevada).

\section{b. Specifications}

Our primary specifications regress premiums at the plan-year level on indicators for insurance reforms, which vary at the state-year level. ${ }^{20}$ All models are estimated by weighted least squares, using the average number of enrollees in each plan (over time) as weights. The weights help us to obtain representative estimates of the effect of reform and also act to reduce the influence of smaller markets, in which the smaller sample sizes imply a greater risk of measurement error. We report standard errors clustered by state to allow for correlation in the error terms across plans within the same state.

As noted earlier, we estimate all models separately by insurance type (self-insured and fully insured). The baseline specification is as follows:

$$
\text { (1) } \begin{aligned}
\ln \left(\text { premium }_{p(m) t}\right. & =\alpha+\gamma \text { Tort Reform }_{m t-1}+\text { pdemographics }_{p(m) t}+\text { Өplan design }_{p(m) t} \\
& +\rho_{p(m)}+\tau_{t}+\varepsilon_{p(m) t}
\end{aligned}
$$

The subscript $p(m) t$ refers to a plan $p$ (which is defined within a particular market $m$ ) and year $t$. TortReform is an indicator variable that takes a value of 1 in the year following the implementation of the reform in question. This lag reflects the timing of insurance contracts, which are typically finalized three or more months prior to the calendar year in which they take effect. Recall also the reform database codes reforms as present if enacted by July. Thus, a reform implemented in June 2002 can impact premiums for 2003 and beyond. (Subsequent specifications include a more flexible lag structure.) We

\footnotetext{
${ }^{20}$ Of the 139 geographic markets represented in LEHID, 138 can be matched uniquely to a single state. Plans in the Rhode Island/southern Massachusetts market are matched with reform data for Massachusetts; this choice is immaterial as neither state enacted or repealed any of the seven reforms.
} 
present estimates including each of the four reforms described above singly as well as altogether. In addition, we report specifications using the sum of the seven most common reforms. This index, which incorporates reforms that were not adopted frequently enough during our study period to permit individual consideration, allows us to test the average impact of introducing an additional liability limitation.

Equation (1) also includes the two time-varying plan-specific measures available in the data: demographics and plan design. Both are associated with higher costs and should have positive coefficient estimates. $\rho_{p(m)}$ and $\tau_{t}$ represent plan and year fixed effects, respectively. The estimate of $\gamma$ therefore captures the impact of reforms on premium growth for the same healthplan over time, controlling for average national premium growth. (Note that state fixed effects are superfluous, as plans are specific to markets and markets are finer geographic areas than states.) Including plan fixed effects reduces the potential for omitted variables bias due to changes in the composition of plans over time. For example, if tort reform reduces premiums and prompts more employers to select more expensive carrier-plantype combinations (e.g. the Blue Cross PPO instead of the Humana PPO or HMO), the effect of tort reform on premiums will be understated in the absence of plan fixed effects.

A consequence of these fixed effects is that only employers who appear in the sample for two or more years and who "straddle" one or more reforms can help to identify the coefficients of interest. Although the median number of years an employer appears in our sample is only two, virtually all employers are active in multiple markets. As there are 33 separate legal changes (see Appendix Table 3), most employers are affected by some reform. In addition, when we estimate leads and lagged effects of reform, more firms will contribute identifying information.

After estimating these baseline regressions, we expand the model in three ways. First, we include leads and lags of TortReform. The coefficients on the former will reveal the presence of legislative endogeneity, if any, and on the latter the timing of the response to the legislation. On one hand, a delayed response is likely given uncertainty around the effect of the law and the lag before changes in damage awards, malpractice premiums, and physician behavior are reflected in healthcare costs. On the other, responses could 
even precede effective reform dates if insurance carriers and self-insured firms incorporate the expected impact of reform in their premiums.

Second, we test whether the effect of reform varies by plan type (indemnity, PPO, POS and HMO). The results will reveal whether reform has less of an impact in a managed care environment. The third and final extension of the basic model exploits differences in the market concentration of insurance providers as another layer of variation in addition to the adoption of reform. We anticipate that any cost reductions induced by tort reform should be passed on to a greater degree in more competitive markets. $^{21}$ We use the number of carriers per market as a proxy for the degree of competition. Given the non-random nature of the sample, the number of carriers is less likely to be measured with error than alternative measures of market competition such as the HHI. To allow for a non-linear relationship between competition and cost passthrough, we interact TortReform with indicators for quintiles of the distribution of number of carriers (NC) per market-year:

$$
\begin{aligned}
\ln {\text { (premium })_{p(m) t}} & \alpha+\sum_{i=1}^{5} \gamma_{i} \text { NC }_{\text {quintile }} * \text { Tort }_{\text {Reform }} \text { Tht }-1+ \\
& +\sum_{i=1}^{4} v_{i} N C \text { quintile }_{i m t}+\text { pdemographics }_{p(m) t} \\
& + \text { Pplan design }_{p(m) t}+\rho_{p(m)}+\tau_{t}+\varepsilon_{p(m) t}
\end{aligned}
$$

This specification includes main effects for the quintiles (save one omitted category), as there is some movement across quintiles over time.

\section{Results}

\section{a. Main findings}

Table 1 presents results from our baseline specification, which reflects a simple before-after estimate of the effect of each reform in the self-insured and fully insured samples. In the self-insured sample, three of the four reforms are associated with a

\footnotetext{
${ }^{21}$ Although it is theoretically possible for a monopoly to pass on as much or more of a cost reduction as a competitive firm, this requires the elasticity of demand to increase in price. More importantly, if firms engage in first-degree price discrimination, then a monopoly will always pass through less of a cost reduction than a more competitive market. Dafny (2009) shows insurers in the least competitive markets effectively engage in first-degree price discrimination, charging higher premium increases to employers experiencing positive profit shocks.
} 
statistically-significant decline in premiums on the order of 1.3 to 1.4 percent. The exception is caps on punitive damages, for which the point estimate is negative but imprecisely estimated. Column 5 reports the result obtained using the sum of all seven possible reforms, which represents the intensity of tort reforms in a state-year. The point estimate of $-.003(\mathrm{p}<.10)$ implies that moving from no limitations on tort liability to seven reduces premiums by 2.1 percent. Of course, this specification weights all reforms equally. If some reforms have little effect, aggregating them masks the effect of individually significant reforms. However, because reforms are sometimes implemented at the same time, estimating them separately may overstate their impact. Thus, column 6 includes the four key tort reforms from columns 1 through 4 simultaneously. The collateral source rule and caps on non-economic damages have clear independent effects, while the coefficient on joint and several liability is now small and statistically insignificant. We draw no inference here because there are few cases in which joint and several liability reform takes place separately from other reforms and hence it is difficult to identify its effect. We reject the null hypothesis that all reforms have no impact with a p-value of 0.03 .

In the sample of fully insured plans, the coefficients on reforms are not statistically significant when entered separately (columns 1-4) or as a sum (column 5). However, the results in Column 6 (four key reforms entered simultaneously) suggest that caps on punitive damages decrease insurance premiums while caps on non-economic damages increase insurance premiums. The joint test of reforms is not significant, however, with a p-value of .16 .

Next, we expand the models in columns 1 through 4 by including leads and lags for each reform. Figures 1 and 2 present estimates from these models for the self-insured and fully insured samples, respectively (corresponding to Tables 2 and 3). The excluded category is three years or more prior to reform. None of the leads in Table 2 is statistically significant. Thus, there is no evidence that plans in states with future reforms exhibit different premium growth than plans in states without such reforms. In addition, there is no significant effect of reform in the year of implementation. Based on the point estimates, the premium reduction associated with reforms generally increases slightly over time. By three years post-reform, all four of the reforms are associated with 
significant reductions in premiums. Only reforms to joint and several liability do not appear to have increasing effects over time.

By contrast, in the fully-insured sample we do not find responses to any of the reforms. A pre-reform trend is evident for caps on punitive damages, implying some states may have enacted these reforms in response to rising full insurance premiums. The pattern of coefficients for the other three reforms do not suggest legislative endogeneity. For caps on non-economic damages, premiums increase two years prior to reform, but remain roughly constant thereafter. Neither collateral source nor joint and several liability reforms show signs of legislative endogeneity, and the latter is associated with a premium increase three years out. In sum, we find no evidence that tort reform reduces fullinsurance premiums.

We pause here to note the magnitude and plausibility of some of the estimated coefficients. The point estimates we obtain using the self-insured sample and the model including the four key reforms (Table 1, Column 6) sum to -2.3 percent. These results are smaller than Kessler and McClellan's estimate of a 4 to 9 percent reduction from "direct reforms" for Medicare heart patients. However, the specifications that permit the effect to vary over time reveal deeper reductions three or more years after the passage of reform. We caution that our results are not directly comparable to those of Kessler and McClellan because we examine a slightly different reform mix, ${ }^{22}$ Kessler and McClellan measure costs (whereas we measure insurance premiums), and their study pertains to one medical condition and the elderly population.

\section{b. Extensions and Robustness}

Do Effects Vary by Plan-Type? Table 4 presents results obtained when interacting the individual reform dummies or the sum of reforms with plan type, using the self-insured sample. (Because over $90 \%$ of fully insured plans are HMOs, we lack the power to estimate this model using the fully insured sample.) The coefficients on the interactions

\footnotetext{
${ }^{22}$ Kessler and McClellan define "direct reforms" as caps on punitive or non-economic damages, collateral source reform, or reduction of prejudgment interest. We believe that the abolition of prejudgment interest should have a fairly small impact, as inflation in the years of the study was not high, enabling a fairly straightforward comparison.
} 
with PPO plans are negative and statistically significant in all five specifications. Although the standard errors do not permit strong inferences about differences between the categories, hypothesis tests confirm that the PPO interactions are statistically different from the HMO or POS interactions in half of the specifications.

There are no significant reactions among managed-care plans (HMO and POS plans), with the exception of joint and several liability reform. We return to this result momentarily. In addition, we do not find significant responses among indemnity plans, although a priori we anticipated a response similar to that of PPOs. However, there was a rapid shift away from indemnity plans over the course of our study period, so these estimates are obtained using a very small sample.

To confirm the robustness of the results by plan type, Appendix Table 4 reports the coefficients obtained when estimating this specification on the combined (fully insured + self-insured ) sample. The results are strikingly similar to Table 4 and further confirm the hypothesis that HMOs are largely unaffected by reform.

The negative, significant effect of joint and several liability reform on HMO premiums may reflect the fact that joint and several liability reform directly reduces liability pressures for HMOs. In recent decades courts have found HMOs (and not just hospitals) liable under joint and several liability. ${ }^{23}$ However, we take the result as suggestive but not conclusive. It is difficult to identify the effect of joint and several liability separately from that of the other reforms (see Table 1, Column 6). Furthermore, the impact of joint and several liability reform on HMOs is small and imprecisely estimated in the pooled sample in Appendix Table 4.

On balance, the results suggest that the premium reductions associated with tort reform are generally concentrated in the PPO category. These findings support the hypothesis that managed care and tort reform are partial substitutes for reducing medical expenditures. In addition, the lack of response by HMO plans in the self-insured sample is consistent with our finding of little effect in the fully insured sample, which is dominated by HMOs.

\footnotetext{
${ }^{23}$ Currie and MacLeod (2008) argue that joint and several liability reform better aligns incentives by placing more liability on the agent-doctor, who is better able to prevent harm.
} 
Do Effects Vary by Concentration of the Local Insurance Market? Holding constant the impact of tort reform on healthcare costs, premium reductions should be steeper in more competitive insurance markets. To explore this prediction, we interact the tort reform indicators from our baseline models with quintiles for the number of insurers in the relevant market-year. In the self-insured sample (Table 5), there is no significant premium response to caps on punitive damages in any quintile, as in the baseline specification. However, for all other reforms, there is a contrast in the results for the least competitive quintile (in which reductions are never significant and point estimates are small) and the two most competitive quintiles (in which reductions are almost always significant and the magnitudes are larger relative to the least competitive quintile), although the differences are only statistically significant for caps on non-economic damages. The results for the fully-insured sample reveal no evidence of greater responsiveness to tort reform in more competitive markets, consistent with the general weakness of the findings from the basic specifications.

Selection out of the Fully Insured Sample. Although we have treated the self-insured and fully insured samples separately, among the set of large firms in our sample these two options are substitutes. Thus, high premiums in one sector could spur growth in the other. If movement in and out of these samples is correlated with tort reform, some of our estimated effects could be affected by changes in sample composition. (Given the inclusion of plan fixed effects in all models, such movements are unlikely to affect the results regardless of whether they are correlated with tort reform. It would have to be the case that new self-insured plans spurred by tort reform, for example, have systematically faster or slower growth than pre-existing self-insured plans.) For good measure, however, we examine whether the propensity to fully insure is affected by tort reform. For this analysis, we aggregate the data to the employer-market-year level and estimate models using the proportion of employees enrolled in fully insured plans as the dependent variable. These models include the leads and lags of the individual reforms and employer-market and year fixed effects. Observations are weighted by the average number of enrollees in each employer-market. The results are presented in Table 6. We 
find no evidence of selection into or out of the fully insured market (or equivalently, out or into the self-insured market) in the years preceding (or following) any of the reforms.

Changes in Plan Quality. We control for plan design throughout the analysis so we can make reliable price comparisons for the same plan over time. One concern is that our plan design variable may be an imperfect proxy for plan generosity. For example, one way employers may respond to a decrease (increase) in costs is through more (less) generous benefits. This would lead to downward-biased (i.e. conservative) estimates of the impact of reforms. To gauge whether plan generosity changes over time, Table 7 presents estimates of the baseline specifications using plan design as the dependent variable (rather than a control) and the self-insured sample Both collateral source and joint and several liability reforms are associated with small but significant increases in plan generosity. To the extent that our measure of plan design is correlated with omitted measures of plan generosity, our estimates of the premium reductions associated with these two reforms will be conservative.

\section{Conclusion}

Tort reform is among the most popular cost-control initiatives implemented by individual states. President Obama recently reasserted his commitment to some tort reform as a way to reduce medical costs, although he stopped short of advocating caps on damages. ${ }^{24}$ Prior to this study, the only rigorous empirical estimates of the impact of reforms were based on particular conditions with heavy malpractice caseloads, namely deliveries and heart disease. These may not be representative of healthcare at large and have led to wide variations in the estimated impact of reform. For example, in 2002 the Department of Health and Human Services asserted that tort reform could reduce

24 Remarks by the President to the Annual Conference of the American Medical Association (2009). Available at http://www.whitehouse.gov/the press_office/ Remarks-by-the-President-to-the-AnnualConference-of-the-American-Medical-Association/. 
healthcare costs by $5 \%-9 \%$, while the Congressional Budget Office concluded reforms would have little impact. ${ }^{25}$

To assess the aggregate impact of reforms, we used a database of employersponsored healthplans covering over 10 million nonelderly Americans each year. To the extent private insurers pass through cost changes associated with reforms, premiums will reflect the impact of reforms across the entire spectrum of healthcare. We find evidence that caps on non-economic damages, collateral source reform, and joint and several liability reform reduce self-insured premiums by 1 to 2 percent each. When the effects of reform are estimated jointly, caps on non-economic damages and collateral source remain independently significant and their point estimates imply a joint reduction of healthcare costs of 2.3 percent. In addition, the effect of reform tends to increase over time.

The magnitudes of the estimated effects far exceed any savings from reducing direct liability costs, which are at most two percent of total health costs. For example, suppose caps on non-economic damages reduce awards and malpractice costs by onequarter (a high-end estimate). This would reduce health care costs by $0.5 \%$, only a fraction of our estimated impact of imposing these caps $(\sim 1.3 \%)$. Thus, if the point estimates are correct, treatment intensity must have been affected by reform.

By contrast, we do not find evidence of reductions in fully insured premiums. The absence of a response is consistent with monitoring of medical practices by HMOs, which comprise 90 percent of fully insured plans. We corroborate this conjecture by finding that cost reductions in our self-insured sample are concentrated outside of managed care plans. Thus, we conclude that tort reform reduces medical costs outside of a managed care environment, implying that physicians are most responsive to liability pressures when they have the most control over treatment choices. These results

\footnotetext{
${ }^{25}$ U.S. Department of Health and Human Services. Confronting the New Health Care Crisis: Improving Health Care Quality and Lowering Costs by Fixing Our Medical Liability System (2002). http://aspe.hhs.gov/daltcp/reports/litrefm.pdf, p. 5. Congressional Budget Office. Limiting Tort Liability for Medical Malpractice. Washington, D.C.: Congressional Budget Office (2004). Available at http://www.cbo.gov/ftpdocs/49xx/doc4968/01-08-MedicalMalpractice.pdf.
} 
constitute the first evidence that tort reform reduces healthcare expenditures broadly (albeit not in a managed-care environment). Importantly, our results suggest the savings generated by tort reform are not offset by increases in induced demand or increases in short-run remediation of medical errors. To understand the social welfare implications of these reforms, however, additional research on health outcomes and long-run costs is needed. 


\section{References}

Altman, Daniel; David Culter, and Richard Zeckhauser. 2003. Enrollment Mix, Treatment Intensity, and Cost in Competing Indemnity and HMO Plans. Journal of Health Economics, 22(1): 23-45.

American Tort Reform Association. 2007. State and Federal Reforms. http://www.atra.org/reforms/.

America's Health Insurance Plans (AHIP). 2006. Health Insurance Premium Growth Slows Despite Increased Utilization, Higher Costs. http://www.ahip.org/content/pressrelease.aspx?docid=14702.

Arlen, Jennifer and W. Bentley MacLeod. 2003. Malpractice Liability for Physicians and Managed Care Organizations. New York University Law Review 78: 1929-2005.

Avraham, Ronen. 2006. Database of State Tort Law Reforms. Working Paper No. 06-08. Northwestern Law and Econ Research Paper. Available at: http://ssrn.com/abstract=902711.

Avraham, Ronen. 2006. Putting a Price on Pain-and-Suffering Damages: A Critique of the Current Approaches and Preliminary Proposal for Change. Northwestern University Law Review 100:87-120.

Baicker, Katherine, and Amitabh Chandra. 2005. The Consequences of the Growth of Health Insurance Premiums. Working Paper No. 11160. National Bureau of Economic Research, Cambridge, Mass.

Blomqvist, A. (1991), “The Doctor as Double Agent: Information Asymmetry, Health Insurance, and Medical Care", Journal of Health Economics 10(4): 411-432.

Carlin, Caroline and Robert Town. "Adverse Selection, Welfare, and the Optimal Pricing of Employer-Sponsored Health Plans," mimeo 2008.

Chernew, Michael, David Cutler, and Patricia Keenan. 2005. Increasing Health Insurance Costs and the Decline in Insurance Coverage. Health Services Research 40(4):10211039.

Congressional Budget Office. 2004. Limiting Tort Liability for Medical Malpractice. Washington, D.C.: Congressional Budget Office. Available at http://www.cbo.gov/ftpdocs/49xx/doc4968/01-08-MedicalMalpractice.pdf.

Cromwell, Jerry, and Janet B. Mitchell. 1986. Physician-Induced Demand for Surgery. Journal of Health Economics 5(4):293-313.

Currie, Janet, and W. Bentley MacLeod. 2008. Tort Reform and Birth Outcomes. Quarterly Journal of Economics 123(2): 795-830.

Currie, Janet, and W. Bentley MacLeod. 2006. First Do No Harm? Tort Reform and Birth Outcomes. Working Paper No. 12478. National Bureau of Economic Research, Cambridge, Mass. Available at http://columbia.edu/ wbm2103/Courses/PapersSLEPP/macleod.pdf.

Danzon, Patricia M. 1986. The Frequency and Severity of Medical Malpractice Claims: New Evidence. Law and Contemporary Problems 49(2):57-84. 
Danzon, Patricia M., Mark V. Pauley, and Raynard S. Kington. 1990. The Effects of Malpractice Litigation on Physicians' Fees and Income. American Economic Review 80(2):122-27.

Danzon, P.M., A. J. Epstein, and S. J. Johnson, 2004, The Crisis in Medical Malpractice Insurance, in: R.Herring and R. Litan, eds., Brookings-Wharton Papers on Financial Services (Washington, DC: Brookings Institution Press), 55-95.

Dafny, Leemore. "Are Health Insurance Markets Competitive? A Direct Test of Price Discrimination." NBER Working Paper 14572, forthcoming in The American Economic Review.

Dubay, Lisa, Robert Kaestner, and Timothy Waidmann. 1999. The Impact of Malpractice Fears on Caesarian Section Rates. Journal of Health and Economics 18(4):491-522.

Dubay, Lisa, Robert Kaestner, and Timothy Waidmann. 2001. Medical Malpractice Liability and its Effect on Prenatal Care Utilization and Infant Health. Journal of Health Economics 20:591-611.

Glied, Sherry. 2000. "Managed Care" in Handbook of Health Economics, A.J. Culyer and J.P. Newhouse, eds. New York: Elsevier, chapter 13.

Glied, Sherry. 2003. Health Care Costs on the Rise Again. Journal of Economic Perspectives 17(2): 125-148.

Gruber, Jonathan, John Kim, and Dina Mayzlin. "Physician Fees and Procedure Intensity: The Case of Cesarean Delivery." 1999. Journal of Health Economics $18,473-490$.

Holtz-Eakin, Douglas. 2004. The Effects of Torts Reform: Evidence from the States. Washington, D.C.: Congressional Budget Office.

Hyman, David, Bernard Black, Charles Silver, William Sage, and Kathryn Zeiler. 2007. Do Defendants Pay What Juries Award? Post-Verdict Haircuts in Texas Medical Malpractice Cases, 1988-2003. Journal of Empirical Legal Studies 4(1):3-68.

Kessler, Daniel P. 2006. The Determinants of the Cost of Medical Liability Insurance. Physician Insurers Society of America: available at http://www.piaa.us/pdf files/press releases/Kessler Malpins Report.pdf

Kessler, D.P. (1996). "Institutional Causes of Delay in the Settlement of Legal Disputes", Journal of Law, Economics, and Organizations, 12(2), pp 432-460.

Kessler, Daniel, and Mark McClellan. 1996. Do Physician's Practice Defensive Medicine? Quarterly Journal of Economics 111:353-90.

Kessler, Daniel, and Mark McClellan. 2002. Malpractice Law and Health Care Reform: Optimal Liability Policy in an Era of Managed Care. Journal of Public Economics 84(2):175-97.

National Conference of State Legislators. 2007. Medical Malpractice Tort Reform. http://www.ncsl.org/standcomm/sclaw/medmaloverview.htm.

Pauly, Mark, Christy Thompson, Thomas Abbott, James Margolis, and William Sage. 2006. Who Pays? The Incidence of Malpractice Premiums. Forum for Health and Economic Policy 9(1):Art.2.

Polinsky, A. Mitchell. 1997. Are Punitive Damages Really Insignificant, Predictable, and Rational? A Comment on Eisenberg et al. The Journal of Legal Studies 26(2):663-77.

Silver, Charles, Kathryn Zeiler, Bernard Black, David Hyman, and William Sage. 2006. Physician's Insurance Limits and Malpractice Payouts: Evidence from Texas Closed Claims. Working Paper. University of Texas, Austin, TX. 
Sloan, Frank A., Kathryn Whetten-Goldstein, Penny B. Githens, and Stephen S. Entman. 1995. Effects of the Threat of Medical Malpractice Litigation and Other Factors on Birth Outcomes. Medical Care 33:700-14.

Studdert, David M., Michelle M. Mello, William M. Sage, Catherine M. DesRoches, Jordon Peugh, Kinga Zapert, and Troyen A. Brennan. 2005. Defensive Medicine Among HighRisk Specialist Physicians in a Volatile Malpractice Environment. The Journal of the American Medical Association 293:2609-17.

Thurston, Norman K. 2001. Physician Market Power-Evidence from the Allocation of Malpractice Premiums. Economic Inquiry 39(3):487-98.

U.S. Congress. Office of the Technology Assessment. 1993. Impact of Legal Reforms on Medical Malpractice Costs. Washington, D.C.: U.S. Government Printing Office, pp. 57-75, 105-111.

U.S. Congress. Office of the Technology Assessment. 1994. Defensive Medicine and Medical Malpractice, OTA-H--602. Washington, D.C.: U.S. Government Printing Office.

U.S. Department of Health and Human Services. 2002. Confronting the New Health Care Crisis: Improving Health Care Quality and Lowering Costs by Fixing Our Medical Liability System. http://aspe.hhs.gov/daltcp/reports/litrefm.pdf, p. 5.U.S. General Accounting Office (GAO). 2003. Malpractice: Implications of Rising Premiums on Access to Health Care. 03-836. August 2003.

Westlaw. 2006. 50 State Statutory Surveys: Health Care Medical Malpractice

The White House. 2004. President's Remarks at the 2004 President's Dinner. Available at http://www.whitehouse.gov/news/releases/2004/07/20040721-14.html. 
Table 1: Effect of Reforms on Premiums

\begin{tabular}{|c|c|c|c|c|c|c|c|c|c|c|c|c|}
\hline & \multicolumn{6}{|c|}{ Self-Insured Sample } & \multicolumn{6}{|c|}{ Fully-Insured Sample } \\
\hline & (1) & (2) & (3) & (4) & (5) & (6) & (1) & (2) & (3) & (4) & (5) & (6) \\
\hline \multirow[t]{2}{*}{ Caps Punitive Reform } & -0.008 & & & & & -0.000 & -0.009 & & & & & -0.028 \\
\hline & $(0.006)$ & & & & & $(0.006)$ & $(0.008)$ & & & & & $(0.011)^{* *}$ \\
\hline Collateral Source & & -0.014 & & & & -0.010 & & 0.010 & & & & 0.016 \\
\hline Reform & & $(0.005)^{* * *}$ & & & & $(0.005)^{* *}$ & & $(0.010)$ & & & & $(0.013)$ \\
\hline Caps Non-Economic & & & -0.013 & & & -0.011 & & & 0.019 & & & 0.024 \\
\hline Damages & & & $(0.006)^{* *}$ & & & $(0.005)^{* *}$ & & & $(0.013)$ & & & $(0.014)^{*}$ \\
\hline Joint \& Several & & & & -0.013 & & -0.002 & & & & 0.008 & & -0.009 \\
\hline Liability & & & & $(.005)^{* *}$ & & $(0.004)$ & & & & $(0.011)$ & & $(0.014)$ \\
\hline $\begin{array}{l}\text { Sum of Seven Common } \\
\text { Reforms }\end{array}$ & & & & & $\begin{array}{c}-0.003 \\
(0.002)^{*}\end{array}$ & & & & & & $\begin{array}{c}0.005 \\
(0.004)\end{array}$ & \\
\hline $\begin{array}{l}\text { Joint Test of Reforms } \\
\text { (p-value) }\end{array}$ & & & & & & 0.032 & & & & & & 0.162 \\
\hline R-Squared & 0.789 & 0.789 & 0.789 & 0.789 & 0.789 & 0.789 & 0.858 & 0.858 & 0.858 & 0.858 & 0.858 & 0.858 \\
\hline
\end{tabular}

$* \mathrm{p}<0.10, * * \mathrm{p}<0.05, * * * \mathrm{p}<0.01$

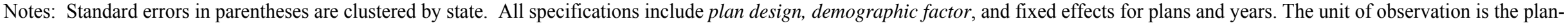
year. Observations are weighted by the mean number of enrollees in each plan. N=163,857 for Self-Insured; N=76,803 for Fully-Insured. 
Table 2: Effect of Reforms on Self-Insured Premiums, by Year

\begin{tabular}{l|cccc}
\hline & Caps Punitive & Collateral Source & $\begin{array}{c}\text { Caps Non- } \\
\text { Economic }\end{array}$ & $\begin{array}{c}\text { Joint \& Several } \\
\text { Liability }\end{array}$ \\
\hline -2 Year Reform & -0.000 & -0.005 & 0.003 & 0.006 \\
-1 Year Reform & $(0.011)$ & $(0.008)$ & $(0.006)$ & $(0.010)$ \\
& -0.004 & 0.004 & 0.005 & -0.003 \\
Year of Reform & $(0.016)$ & $(0.012)$ & $(0.007)$ & $(0.007)$ \\
& -0.004 & -0.006 & -0.004 & -0.011 \\
+1 Year Reform & $(0.009)$ & $(0.014)$ & $(0.009)$ & $(0.008)$ \\
& -0.007 & -0.006 & -0.014 & -0.020 \\
+2 Year Reform & $(0.012)$ & $(0.013)$ & $(0.010)$ & $(0.006)^{* * *}$ \\
& -0.015 & -0.022 & -0.008 & -0.014 \\
$\geq+3$ Years Reform & $(0.017)$ & $(0.015)$ & $(0.009)$ & $(0.010)$ \\
& -0.027 & -0.023 & -0.018 & -0.015 \\
R-Squared & $(0.013)^{* *}$ & $(0.009)^{* *}$ & $(0.009)^{* *}$ & $(0.007)^{*}$ \\
\hline
\end{tabular}

$* \mathrm{p}<0.10, * * \mathrm{p}<0.05, * * * \mathrm{p}<0.01$

Notes: Standard errors are clustered by state. All specifications include plan design, demographic factor, and fixed effects for plans and years. The unit of observation is the plan-year. Observations are weighted by the mean number of enrollees in each plan. $\mathrm{N}=163,857$. 
Table 3: Effect of Reforms on Fully-Insured Premiums, by Year

\begin{tabular}{l|cccc}
\hline & Caps Punitive & Collateral Source & $\begin{array}{c}\text { Caps Non- } \\
\text { Economic }\end{array}$ & $\begin{array}{c}\text { Joint \& Several } \\
\text { Liability }\end{array}$ \\
\hline -2 Year Reform & 0.020 & -0.009 & 0.004 & 0.010 \\
-1 Year Reform & $(0.008)^{* *}$ & $(0.011)$ & $(0.012)$ & $(0.015)$ \\
& 0.022 & 0.006 & 0.029 & 0.008 \\
Year of Reform & $(0.012)^{*}$ & $(0.020)$ & $(0.016)^{*}$ & $(0.017)$ \\
& 0.023 & -0.001 & 0.024 & -0.003 \\
+1 Year Reform & $(0.012)^{*}$ & $(0.028)$ & $(0.018)$ & $(0.024)$ \\
& 0.002 & 0.006 & 0.023 & -0.004 \\
+2 Year Reform & $(0.012)$ & $(0.026)$ & $(0.019)$ & $(0.014)$ \\
& -0.002 & 0.003 & 0.051 & -0.003 \\
Z+3 Years Reform & $(0.014)$ & $(0.032)$ & $(0.020)^{* *}$ & $(0.029)$ \\
& -0.016 & 0.013 & 0.029 & 0.029 \\
R-Squared & $(0.016)$ & $(0.011)$ & $(0.022)$ & $(0.011)^{* * *}$ \\
\hline
\end{tabular}

$* \mathrm{p}<0.10, * * \mathrm{p}<0.05, * * * \mathrm{p}<0.01$

Notes: Standard errors are clustered by state. All specifications include plan design, demographic factor, and fixed effects for plans and years. The unit of observation is the plan-year. Observations are weighted by the mean number of enrollees in each plan. $\mathrm{N}=76,803$. 
Table 4: Effect of Reforms on Self-Insured Premiums, by Plan Type

\begin{tabular}{l|ccccc}
\hline & Caps Punitive & $\begin{array}{c}\text { Collateral } \\
\text { Source }\end{array}$ & $\begin{array}{c}\text { Caps Non- } \\
\text { Economic }\end{array}$ & $\begin{array}{c}\text { Joint \& Several } \\
\text { Liability }\end{array}$ & $\begin{array}{c}\text { Sum of } \\
\text { Reforms }\end{array}$ \\
\hline HMO*Reform & 0.000 & -0.010 & 0.032 & -0.027 & 0.003 \\
& $(0.004)$ & $(0.012)$ & $(0.019)$ & $(0.009)^{* * *}$ & $(0.006)$ \\
POS*Reform & 0.021 & -0.015 & -0.007 & -0.002 & -0.001 \\
& $(0.023)$ & $(0.011)$ & $(0.007)$ & $(0.010)$ & $(0.003)$ \\
PPO*Reform & -0.032 & -0.018 & -0.033 & -0.020 & -0.008 \\
& $(0.006)^{* * *}$ & $(0.006)^{* * *}$ & $(0.010)^{* * *}$ & $(0.007)^{* * *}$ & $(0.002)^{* * *}$ \\
Indemnity*Reform & 0.017 & 0.008 & -0.008 & -0.004 & -0.004 \\
& $(0.023)$ & $(0.015)$ & $(0.017)$ & $(0.015)$ & $(0.006)$ \\
\hline p-value for H0: & & & & 0.60 & 0.17 \\
$\quad$ PPO*Reform= & 0.00 & 0.44 & 0.01 & & 0.19 \\
HMO*Reform & & & & & 0.04 \\
PPO*Reform $=$ & 0.04 & 0.78 & 0.03 & 0.789 & 0.789 \\
POS*Reform & & & & & \\
\hline R-Squared & 0.789 & 0.789 & 0.789 & & \\
\hline
\end{tabular}

$* \mathrm{p}<0.10, * * \mathrm{p}<0.05, * * * \mathrm{p}<0.01$

Notes: Standard errors in parentheses are clustered by state. All specifications include plan design, demographic factor, and fixed effects for plans and years. The unit of observation is the plan-year. Observations are weighted by the mean number of enrollees in each plan. $\mathrm{N}=163,857$. 
Table 5: Effect of Reforms on Self-Insured Premiums, by Competitiveness of Insurance Market

\begin{tabular}{l|ccccc}
\hline & Caps Punitive & $\begin{array}{c}\text { Collateral } \\
\text { Source }\end{array}$ & $\begin{array}{c}\text { Caps Non- } \\
\text { Economic }\end{array}$ & $\begin{array}{c}\text { Joint \& } \\
\text { Several } \\
\text { Liability }\end{array}$ & $\begin{array}{c}\text { Sum of } \\
\text { Reforms }\end{array}$ \\
\hline NCq1*Reform & -0.011 & -0.005 & -0.002 & -0.004 & 0.001 \\
NCq2*Reform & $(0.010)$ & $(0.007)$ & $(0.008)$ & $(0.009)$ & $(0.002)$ \\
& -0.011 & -0.012 & -0.015 & -0.024 & -0.004 \\
NCq3*Reform & $(0.009)$ & $(0.006)^{* *}$ & $(0.006)^{* *}$ & $(0.007)^{* * *}$ & $(0.002)^{*}$ \\
NCq4*Reform & -0.004 & -0.011 & -0.008 & -0.024 & -0.003 \\
& $(0.007)$ & $(0.006)^{*}$ & $(0.006)$ & $(0.006)^{* * *}$ & $(0.002)$ \\
NCq5* Reform & -0.008 & -0.019 & -0.017 & -0.015 & -0.006 \\
& $(0.008)$ & $(0.006)^{* * *}$ & $(0.006)^{* * *}$ & $(0.007)^{* *}$ & $(0.002)^{* *}$ \\
\hline R-Squared & -0.010 & -0.016 & -0.021 & -0.008 & -0.003 \\
\hline
\end{tabular}

$* \mathrm{p}<0.10, * * \mathrm{p}<0.05, * * * \mathrm{p}<0.01$

Notes: Standard errors in parentheses are clustered by state; standard errors in brackets are clustered by state-year. All specifications include plan design, demographic factor, and fixed effects for plans and years. The unit of observation is the plan-year. The intervals for the number of carrier quintiles are $[1,9]$ (ncq1) $[10,11]$ (ncq2) $[12,14]$ ncq3 $[15,17]$ (ncq4) and $[18,31]$ (ncq5). Observations are weighted by the mean number of enrollees in each plan. $\mathrm{N}=163,857$. 
Table 6: Effect of Reforms on Percent of Employees in Fully-Insured Plans, By Year

\begin{tabular}{l|cccc}
\hline & Caps Punitive & Collateral Source & $\begin{array}{c}\text { Caps Non- } \\
\text { Economic }\end{array}$ & $\begin{array}{c}\text { Joint \& Several } \\
\text { Liability }\end{array}$ \\
\hline-2 Year Reform & -0.004 & 0.004 & -0.002 & -0.024 \\
-1 Year Reform & $(0.027)$ & $(0.020)$ & $(0.020)$ & $(0.016)$ \\
& -0.017 & 0.026 & -0.028 & -0.003 \\
Year of Reform & $(0.029)$ & $(0.023)$ & $(0.026)$ & $(0.011)$ \\
& -0.054 & 0.000 & -0.019 & 0.005 \\
+1 Year Reform & $(0.045)$ & $(0.021)$ & $(0.028)$ & $(0.014)$ \\
& -0.028 & -0.011 & 0.000 & 0.018 \\
+2 Year Reform & $(0.046)$ & $(0.019)$ & $(0.042)$ & $(0.027)$ \\
& -0.057 & 0.004 & 0.006 & 0.007 \\
$\geq+3$ Years Reform & $(0.054)$ & $(0.030)$ & $(0.043)$ & $(0.027)$ \\
& 0.010 & -0.003 & -0.041 & -0.031 \\
R-Squared & $(0.042)$ & $(0.038)$ & $(0.034)$ & $(0.020)$ \\
\hline
\end{tabular}

$* \mathrm{p}<0.10, * * \mathrm{p}<0.05, * * * \mathrm{p}<0.01$

Notes: Standard errors are clustered by state. All specifications include fixed effects for employer-markets and years. The unit of observation is the employer-market-year. Observations are weighted by the mean number of enrollees in each employer-market. $\mathrm{N}=116,762$. 
Table 7: Effect of Reforms on Generosity of Self-Insured Plans

\begin{tabular}{|c|c|c|c|c|c|c|}
\hline & \multicolumn{6}{|c|}{ Dependent variable is "plan design factor" } \\
\hline & (1) & (2) & (3) & (4) & (5) & (6) \\
\hline Caps Punitive Reform & $\begin{array}{c}0.002 \\
(0.002)\end{array}$ & & & & & $\begin{array}{l}0.001 \\
(0.001)\end{array}$ \\
\hline Collateral Source & & 0.005 & & & & 0.003 \\
\hline Reform & & $(0.001)^{* * *}$ & & & & $(0.002)$ \\
\hline Caps Non-Economic & & & -0.001 & & & -0.003 \\
\hline Damages & & & $(0.002)$ & & & $(0.002)$ \\
\hline Joint \& Several & & & & 0.004 & & 0.003 \\
\hline Liability & & & & $(.002)^{* *}$ & & $(0.003)$ \\
\hline Sum of Reforms & & & & & $\begin{array}{c}0.001 \\
(0.001)\end{array}$ & \\
\hline $\begin{array}{l}\text { Joint Test of Reforms } \\
\text { (p-value) }\end{array}$ & & & & & & 0.010 \\
\hline R-Squared & 0.279 & 0.280 & 0.279 & 0.279 & 0.279 & 0.280 \\
\hline
\end{tabular}

$* \mathrm{p}<0.10, * * \mathrm{p}<0.05, * * * \mathrm{p}<0.01$

Notes: Standard errors in parentheses are clustered by state. All specifications include demographic factor and fixed effects for plans and years. The unit of observation is the plan-year. Observations are weighted by the mean number of enrollees in each plan. $\mathrm{N}=163,857$. 


\section{Figure 1. Coefficients on Leads and Lags: Self-Insured Sample}

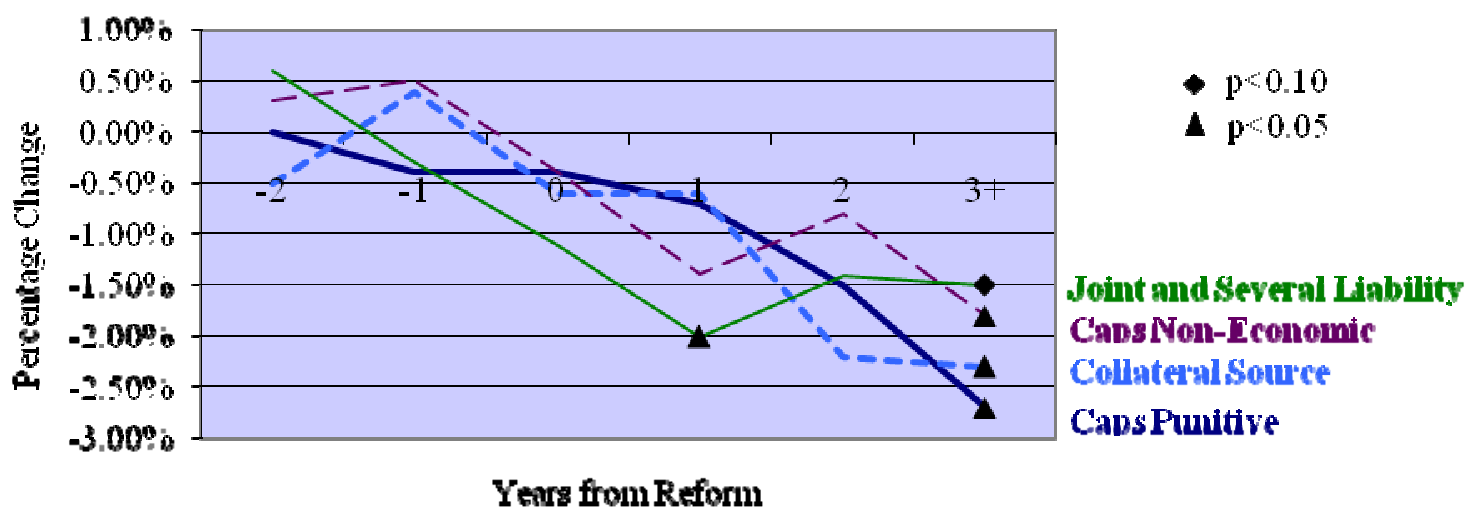

Figure 2. Coefficients on Leads and Lags: Fully-Insured Sample

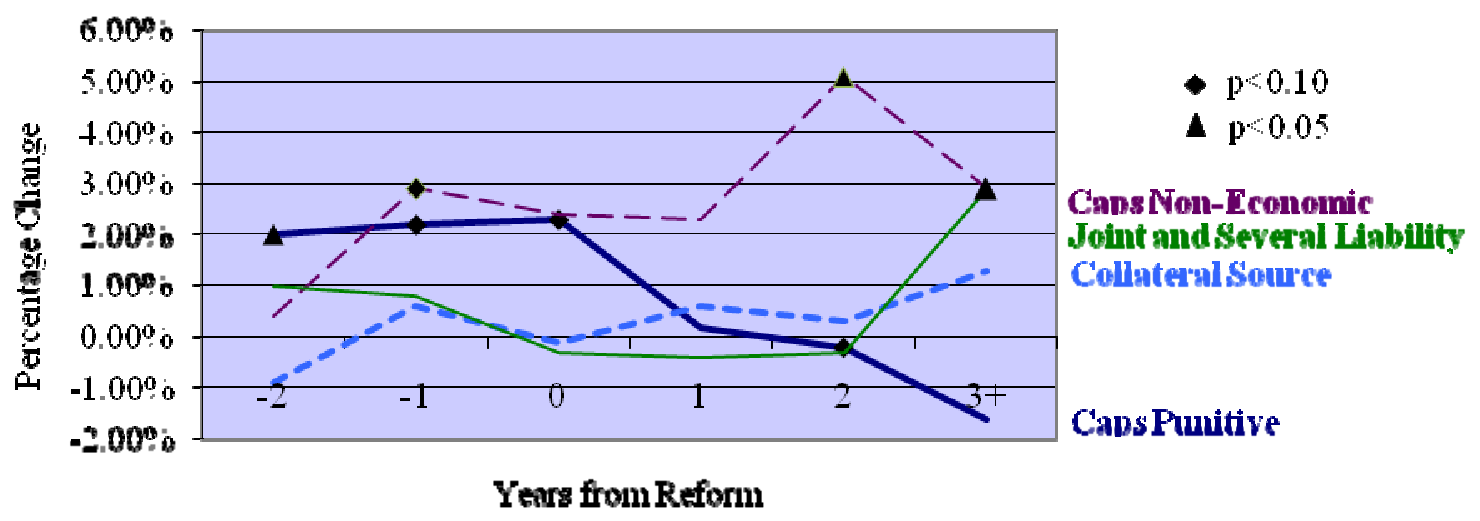


Appendix Table 1. Descriptive Statistics: Self-Insured Plans

\begin{tabular}{|c|c|c|c|c|c|c|c|c|c|}
\hline & 1998 & 1999 & 2000 & 2001 & 2002 & 2003 & 2004 & 2005 & 2006 \\
\hline \multirow[t]{2}{*}{ Premium (\$) } & 4277 & 4306 & 4580 & 5012 & 5644 & 6460 & 7000 & 7460 & 7892 \\
\hline & 1134 & 1230 & 1319 & 1357 & 1437 & 1582 & 1701 & 1799 & 1948 \\
\hline \multirow[t]{2}{*}{ Number of Enrollees } & 191 & 159 & 151 & 169 & 167 & 175 & 170 & 192 & 179 \\
\hline & 726 & 602 & 507 & 576 & 612 & 639 & 530 & 862 & 610 \\
\hline \multirow[t]{2}{*}{ Demographic Factor } & 2.42 & 2.29 & 2.26 & 2.27 & 2.28 & 2.30 & 2.32 & 2.31 & 1.84 \\
\hline & 0.52 & 0.45 & 0.45 & 0.44 & 0.46 & 0.42 & 0.43 & 0.43 & 0.40 \\
\hline \multirow[t]{2}{*}{ Plan Design } & 1.02 & 1.01 & 0.99 & 1.02 & 1.03 & 1.02 & 1.01 & 0.97 & 0.97 \\
\hline & 0.07 & 0.07 & 0.08 & 0.07 & 0.07 & 0.08 & 0.08 & 0.08 & 0.08 \\
\hline \multicolumn{10}{|l|}{ Plan Type } \\
\hline $\mathrm{HMO}$ & $2.5 \%$ & $4.3 \%$ & $6.9 \%$ & $10.0 \%$ & $14.6 \%$ & $16.7 \%$ & $17.5 \%$ & $18.0 \%$ & $19.7 \%$ \\
\hline Indemnity & $34.5 \%$ & $31.8 \%$ & $22.1 \%$ & $16.7 \%$ & $14.2 \%$ & $10.5 \%$ & $7.8 \%$ & $5.9 \%$ & $5.9 \%$ \\
\hline POS & $36.1 \%$ & $27.4 \%$ & $30.5 \%$ & $25.3 \%$ & $20.6 \%$ & $18.0 \%$ & $18.2 \%$ & $16.0 \%$ & $15.9 \%$ \\
\hline $\mathrm{PPO}$ & $26.8 \%$ & $36.5 \%$ & $40.5 \%$ & $48.0 \%$ & $50.6 \%$ & $54.8 \%$ & $56.4 \%$ & $60.0 \%$ & $58.5 \%$ \\
\hline \# of Employers & 180 & 193 & 191 & 233 & 248 & 315 & 238 & 256 & 222 \\
\hline \# of Markets & 139 & 139 & 139 & 139 & 139 & 139 & 139 & 139 & 139 \\
\hline Number of Observations & 12194 & 14117 & 14408 & 18460 & 21303 & 24853 & 20211 & 20794 & 17517 \\
\hline
\end{tabular}

Notes: All statistics are unweighted. The unit of observation is the plan-year, unless noted otherwise. Sample includes all self-insured plans. Standard deviations are reported in italics. Demographic factor reflects age, gender, and family size for enrollees. Plan design measures the generosity of benefits. Both are constructed by the data source and exact formulae are not available. 
Appendix Table 2. Descriptive Statistics: Fully-Insured Plans

\begin{tabular}{|c|c|c|c|c|c|c|c|c|c|}
\hline & 1998 & 1999 & 2000 & 2001 & 2002 & 2003 & 2004 & 2005 & 2006 \\
\hline \multirow[t]{2}{*}{ Premium (\$) } & 3648 & 3904 & 4188 & 4621 & 5339 & 5995 & 6689 & 7181 & 7608 \\
\hline & 995 & 919 & 1010 & 1131 & 1378 & 1465 & 1818 & 2053 & 2251 \\
\hline \multirow[t]{2}{*}{ Number of Enrollees } & 170 & 173 & 164 & 180 & 190 & 190 & 176 & 214 & 236 \\
\hline & 487 & 489 & 420 & 489 & 499 & 561 & 504 & 695 & 749 \\
\hline \multirow[t]{2}{*}{ Demographic Factor } & 2.23 & 2.22 & 2.20 & 2.23 & 2.26 & 2.28 & 2.36 & 2.33 & 1.84 \\
\hline & 0.44 & 0.39 & 0.39 & 0.38 & 0.39 & 0.39 & 0.40 & 0.42 & 0.38 \\
\hline \multirow[t]{2}{*}{ Plan Design } & 1.12 & 1.13 & 1.11 & 1.13 & 1.12 & 1.11 & 1.09 & 1.07 & 1.05 \\
\hline & 0.05 & 0.04 & 0.04 & 0.04 & 0.04 & 0.04 & 0.08 & 0.06 & 0.08 \\
\hline \multicolumn{10}{|l|}{ Plan Type } \\
\hline $\mathrm{HMO}$ & $88.7 \%$ & $90.0 \%$ & $92.6 \%$ & $91.9 \%$ & $90.9 \%$ & $92.7 \%$ & $85.7 \%$ & $90.5 \%$ & $88.8 \%$ \\
\hline Indemnity & $3.0 \%$ & $0.6 \%$ & $0.4 \%$ & $0.1 \%$ & $1.0 \%$ & $0.0 \%$ & $1.9 \%$ & $0.6 \%$ & $0.4 \%$ \\
\hline POS & $6.6 \%$ & $6.7 \%$ & $4.0 \%$ & $4.8 \%$ & $3.0 \%$ & $4.2 \%$ & $4.0 \%$ & $4.5 \%$ & $3.9 \%$ \\
\hline PPO & $1.7 \%$ & $2.4 \%$ & $2.9 \%$ & $3.2 \%$ & $5.0 \%$ & $3.0 \%$ & $8.4 \%$ & $4.4 \%$ & $6.8 \%$ \\
\hline \# of Employers & 181 & 197 & 185 & 226 & 226 & 274 & 194 & 203 & 173 \\
\hline \# of Markets & 139 & 139 & 139 & 139 & 139 & 137 & 138 & 138 & 137 \\
\hline Number of Observations & 9880 & 11561 & 9253 & 10654 & 10236 & 8839 & 6364 & 5679 & 4337 \\
\hline
\end{tabular}

Notes: All statistics are unweighted. The unit of observation is the plan-year, unless noted otherwise. Sample includes all fully insured plans. Standard deviations are reported in italics. Demographic factor reflects age, gender, and family size for enrollees. Plan design measures the generosity of benefits. Both are constructed by the data source and exact formulae are not available. 
Appendix Table 3 (DSTLR ${ }^{\text {rd }}$ )

\begin{tabular}{|c|c|c|c|c|c|c|c|c|c|c|c|}
\hline Year & & 1998 & 1999 & 2000 & 2001 & 2002 & 2003 & 2004 & 2005 & Flips* & Total \\
\hline $\begin{array}{l}\text { Cap Non- } \\
\text { Economic }\end{array}$ & $\begin{array}{l}\text { Enactments } \\
\text { Strike } \\
\text { downs }\end{array}$ & IL,OH & & $\begin{array}{l}\text { ME } \\
\text { OR }\end{array}$ & & & FL,OH,MS & OK,TX & GA,NV,TN & $\begin{array}{l}9 \\
3\end{array}$ & 12 \\
\hline $\begin{array}{l}\text { Caps } \\
\text { Punitive }\end{array}$ & $\begin{array}{l}\text { Enactments } \\
\text { Strike } \\
\text { downs } \\
\end{array}$ & $\begin{array}{l}\mathrm{AK} \\
\mathrm{OH}\end{array}$ & & AL,ME & & & $\mathrm{AR}, \mathrm{MS}$ & ID,MT & $\mathrm{OH}$ & $\begin{array}{l}8 \\
1\end{array}$ & 9 \\
\hline $\begin{array}{l}\text { Collateral } \\
\text { Source }\end{array}$ & $\begin{array}{l}\text { Enactments } \\
\text { Strike } \\
\text { downs } \\
\end{array}$ & $\mathrm{OH}$ & & & $\mathrm{AL}$ & $\mathrm{OH}, \mathrm{PA}$ & WV & OK & & $\begin{array}{l}5 \\
1\end{array}$ & 6 \\
\hline $\begin{array}{l}\text { Joint \& } \\
\text { Several }\end{array}$ & $\begin{array}{l}\text { Enactments } \\
\text { Strike } \\
\text { downs } \\
\end{array}$ & IL,OH & & & & PA & $\mathrm{AR}, \mathrm{OH}, \mathrm{NV}$ & & & $\begin{array}{l}4 \\
2\end{array}$ & 6 \\
\hline $\begin{array}{l}\text { Periodic } \\
\text { Payment }\end{array}$ & $\begin{array}{l}\text { Enactments } \\
\text { Strike } \\
\text { downs } \\
\end{array}$ & & & & & PA & $\mathrm{OH}$ & TX & $\begin{array}{l}\text { GA } \\
\text { AL }\end{array}$ & $\begin{array}{l}4 \\
1\end{array}$ & 5 \\
\hline $\begin{array}{l}\text { Split } \\
\text { Recovery }\end{array}$ & $\begin{array}{l}\text { Enactments } \\
\text { Strike } \\
\text { downs }\end{array}$ & $\begin{array}{l}\text { AK } \\
\text { FL }\end{array}$ & & & & PA & & & CA,MT & $\begin{array}{l}4 \\
1\end{array}$ & 5 \\
\hline $\begin{array}{l}\text { Punitive } \\
\text { Evidence }\end{array}$ & $\begin{array}{l}\text { Enactments } \\
\text { Strike } \\
\text { downs }\end{array}$ & KY & & FL & & & $\mathrm{AR}$ & & & $\begin{array}{l}2 \\
1\end{array}$ & 3 \\
\hline
\end{tabular}

* Because insurance premiums are set the year prior and our insurance data run from 1998 to 2006, the relevant years for identification are changes from 1998 to 2005. 
Appendix Table 4: Effect of Reforms on Premiums, by Plan Type (Self + Fully-Insured Premiums)

\begin{tabular}{|c|c|c|c|c|c|}
\hline & Caps Punitive & $\begin{array}{c}\text { Collateral } \\
\text { Source }\end{array}$ & $\begin{array}{l}\text { Caps Non- } \\
\text { Economic }\end{array}$ & $\begin{array}{c}\text { Joint \& Several } \\
\text { Liability }\end{array}$ & Sum of Reforms \\
\hline \multirow{2}{*}{ HMO*Reform } & -0.010 & -0.001 & 0.023 & -0.006 & 0.004 \\
\hline & $(0.005)^{*}$ & $(0.009)$ & $(0.014)^{*}$ & $(0.010)$ & $(0.004)$ \\
\hline \multirow[t]{2}{*}{ POS*Reform } & 0.025 & -0.009 & -0.003 & 0.003 & 0.001 \\
\hline & $(0.023)$ & $(0.011)$ & $(0.007)$ & $(0.010)$ & $(0.003)$ \\
\hline \multirow[t]{2}{*}{ PPO*Reform } & -0.030 & -0.013 & -0.033 & -0.017 & -0.007 \\
\hline & $(0.006)^{* * *}$ & $(0.008)^{*}$ & $(0.010) * * *$ & $(0.008)^{* *}$ & $(0.003)^{* * *}$ \\
\hline \multirow{2}{*}{ Indemnity*Reform } & 0.020 & 0.013 & -0.006 & 0.007 & -0.002 \\
\hline & $(0.022)$ & $(0.016)$ & $(0.017)$ & $(0.016)$ & $(0.006)$ \\
\hline $\begin{array}{l}\frac{\mathrm{p} \text {-value for } \mathrm{H} 0:}{\mathrm{PPO}^{*} \text { Reform }}= \\
\text { HMO*Reform }\end{array}$ & 0.00 & 0.15 & 0.01 & 0.43 & 0.06 \\
\hline $\begin{array}{c}\text { PPO*Reform }= \\
\text { POS*Reform }\end{array}$ & 0.01 & 0.71 & 0.01 & 0.13 & 0.02 \\
\hline R-Squared & 0.810 & 0.810 & 0.811 & 0.810 & 0.810 \\
\hline
\end{tabular}

$* \mathrm{p}<0.10, * * \mathrm{p}<0.05, * * * \mathrm{p}<0.01$

Notes: Standard errors in parentheses are clustered by state. All specifications include plan design, demographic factor, and fixed effects for plans and years. The unit of observation is the plan-year. Observations are weighted by the mean number of enrollees in each plan. $\mathrm{N}=240,660$. 


\section{Appendix Figure 1: Annual Premium Growth, LEHID vs. KFF/HRET}

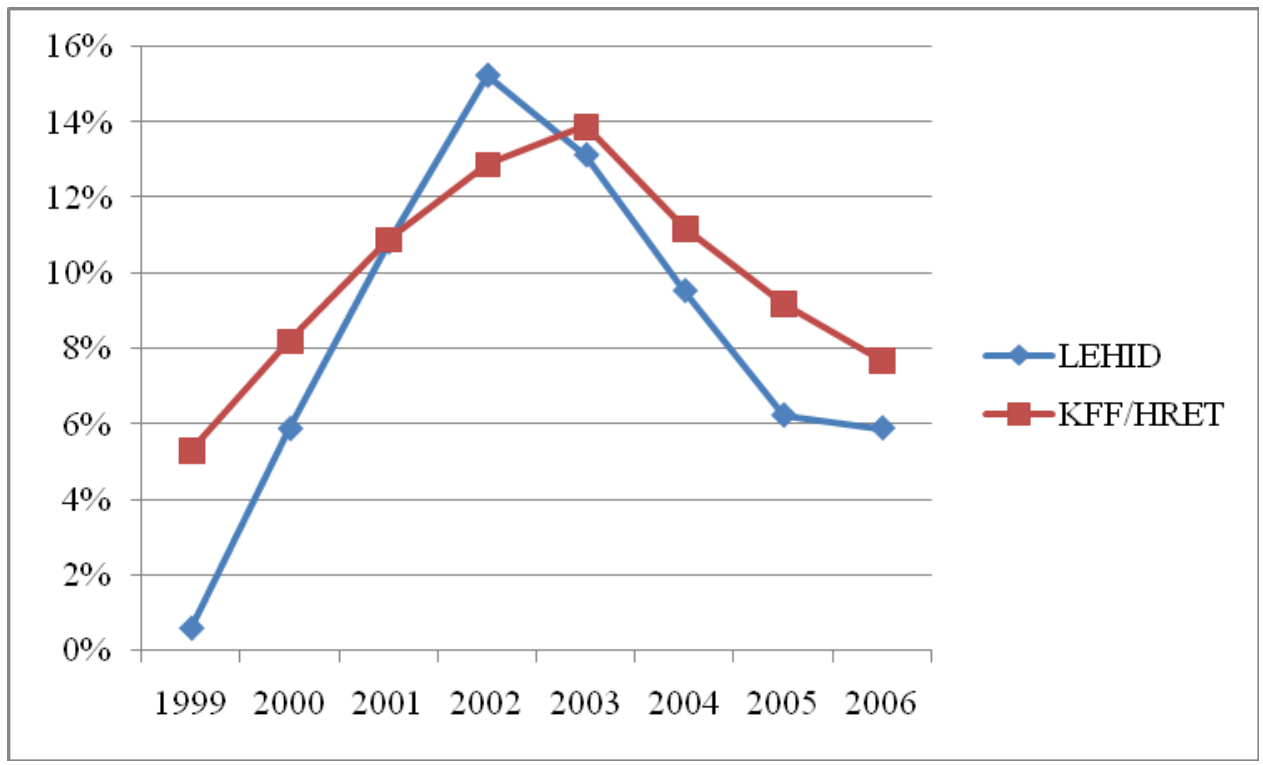

Sources: LEHID sample (all plans), and 2007 Kaiser/HRET Annual Survey of Employer-Sponsored Health Benefits Annual growth rates for the LEHID sample are calculated using employee-weighted average premiums for each year. Both sources combine fully insured and self-insured plans 